\title{
Student Engagement and Course Value as Quality Issues in ICT-based Higher Education
}

\author{
Rugayah Hashim \\ Hashim Ahmad \\ Universiti Teknologi MARA Universiti Teknologi MARA \\ Nor'Aini Ahmad \\ Universiti Teknologi MARA
}

\begin{abstract}
The evolution and revolution of Information and communication technology (ICT) has greatly impacted the world of work and higher education. For the latter, distance education offerings are highly reliant on ICT through the e-learning mode. Due to the economic slowdown and the government's incentive, working adults are returning to school. However, with a different learning environment, adjustments must be made to accommodate the learning process, thus, the purpose of this study was to assess the level of cognitive engagement and course value among adult, distance students toward e-learning. The sample size for this study was 500 adult students and the returned response was 33.8\%. The mean scores for student engagement was 4.48 and course value was 4.36, indicating that student engagement and course value are mediocre. It was reflected in their academic performance where the average CGPA is between 2.50-2.99. These are indicators of low level integration and motivations among adult students in the course of their learning. The university administration needs ensure that the customized learning management system is more user friendly as this would enhance the chances of student success and reduce the rate of attrition.
\end{abstract}

\section{Introduction}

The scope of lifelong learning for institutions of higher education must include policies and practices on adult education or andragogy. As a strategy, adult education through distance education or computerbased education should apply the aspects of social policy such as in the encouragement of working adults to return to school. Consequently, institutions of higher education throughout the world are spending much time, effort and investments to provide their students with quality education. Imitating this practice, the Ministry of Higher
Education Malaysia (MOHE) Malaysia is encouraging individuals to pursue their education part time by providing the necessary incentives such as financial assistance. Time is of essence and as such the common and popular choice is through distance education or off-campus learning. Currently, a third choice is offered to them in the form of electronic distance education. This mode of learning allows universities to move away from the traditional lecture-based andragogy in favor of ICT as the enabler for imparting and internalizing knowledge. However, the most important issue is whether the students are getting back their money's worth through quality education that would be ingrained in them throughout their life time.

\section{Problem Statement}

Bourdieu [3] identified three types of social capital that are interlinked with social benefits of learning; economic, social and cultural. Applying this within the context of adult students enrolled in distance education programs, are they getting their money's worth through part-time study? The value of education should be life-long with high academic performance measured through their cumulative grade point average (CGPA). Getting admitted to a higher level of education, say, a Master's or $\mathrm{PhD}$ program requires a minimum CGPA of 3.00. Hence, this study is apt in order to provide the empirical evidence required by the Ministry of Higher Education Malaysia as well as Universiti Teknologi MARA (UiTM) in deciding whether the learning outcomes have been achieved [5] [16]. At this point of time, no study has been conducted to evaluate the student engagement of adult e-learners at InED, therefore, this research is considered the first of its kind for InED. 


\section{Significance of study}

Academic success is foremost for all institutions of higher learning (IHL) or universities. The students' performances in terms of their final examination results would inadvertently raise the standard of learning and competitiveness in any IHL. In electronic distance education or ePJJ, the standard of academic excellence and performance are still lagging. Comparisons made between the final examination results of full-time students to that of elearning (ePJJ) students have shown marked differences. The findings from this study are significant and would provide the platform and justification for certain changes in ePJJ educational development outlook and policy. Besides the micro importance, at the macro level, there would be significant contribution to the breadth of literature in the field of ICT-based learning in higher education.

\section{Literature review}

How deeply engaged are the students towards their learning process and how much value do they put in the courses or subjects taken? These are questions that require answers through critical analyses of research data. The absorption of education, learning and the students' academic performance reflect how serious and focused these adult, working students are toward their studies. Thus, one of the research objectives is to determine the level of student engagement in e-learning mode for adult students registered with InED. Is it at par with how much time is spent at monthly seminars and discussions or interactions through e-forums?

The relationships between perceived course value and student engagement among electronic distance education or ePJJ students are the bases for this study. Prior to this research, the value of learning by ePJJ students have never been statistically reported nor empirically studied. As a result, the correlation between course value and engagement relative to academic performance has never been proven. Statistically evidenced findings are required to significantly prove this relationship for policy adjustment, upgrade of ICT-based infrastructure and other andragogical development [14]. Coincidentally, this ambiguity was also evidenced in studies by Biggs and Tang's [2] and Volery and Lord [21] where their research outcomes showed that more learner-centered and collaborative activities have proven to enhance a student's learning experience on the effectiveness of online education for adult students. In the case of ePJJ students registered with InED, more face-to-face activities are not possible as seminar meetings are limited to five a semester. Communication and interaction with course facilitators are done through e-forums embedded in the customized learning management system called the $i$-class.

Henceforth, student engagement and perceived course value are believed to be integral to a student's positive learning experience [4] [6]. In fact, Corno and Mandinach [4] stated that a student's engagement was evident when he or she showed prolonged attention to a mentally challenging task which resulted in authentic learning and increased levels of higher order thinking. Applying this to the study and from several years of observation and tracking the feedbacks received from the ePjj students, student engagement will be have a ripple effect on course value and academic performance.

Another study by Richardson and Newby [17] showed that an engaged student is a motivated student, that is, motivation and learning strategies lead to student for proper manipulation of the learning environment. Similar findings were also obtained by Dahan \& Baba [5]. This, in turn leads to perceived course value, which is an equally important concept in evaluating a student's learning experience. Course value is defined as a measure of how valuable a student feels a given course is, including whether the course stimulated the student's interest in the subject matter or whether the course has real-world application and is thought to be important to the adult student's future [4] [18]. Thus, stimulating real-world projects can assist the student in identifying learning goals which could generate increased motivation and learning [10]. It is indeed without doubt that there are a number of factors that influence a student's learning engagement. Consequently, InED's learning strategies for ePJJ inherently affect the students' academic performance. Therefore, a better understanding and comprehension of the ICT-based courses would sustain the students' academic performance [22].

Nevertheless, in contending the success and viability of online coursework, Tham and Werner [20] recommended that issues pertaining to assessment, design, implementation and evaluation of e-learning education be addressed adequately. Simultaneously, DeRouin et al [6], and Fallows and Bharnot [8] reported that behavioral and organizational outcomes of ICT-based education should be measured to determine the end-result of quality education imparted and lifelong learning [11].

\section{Methodology}

This is a quantitative, cross-sectional survey research with 500 respondents sampled from 19 blended learning programs offered by the Institute of Educational Development (InED). Prior to the main study, a preliminary research was conducted to gauge the viability of the research design, analysis strategy and sample size considerations [15] [[9] [12] 
[13] [1]. The online questionnaire consisted of two sections; A and B. Section A has statements measured on a scale of 1 (Very Strongly Disagree) to 7 (Very Strongly Agree). Section B consists of six demographic variables. Using the university's online survey software called Perseus, the e-questionnaire was deployed for three months. Reliability analysis was executed on the instrument with a Cronbach alpha score of 0.940 indicating consistency and trustworthiness of the questionnaire. Parametric analyses were conducted on the data using SPSS.

Lastly, Section B contains six demographic profiles.

\section{Findings}

One hundred and sixty nine completed responses were tabled from the 500 deployed. This comes to about $33.8 \%$. From this percentage, $43.8 \%$ of the students fell under the age range of 21-30 years followed by $45.6 \%$ in the $31-40$ years bracket and $10.7 \%$ respondents are aged between $41-50$ years (Figure 1).

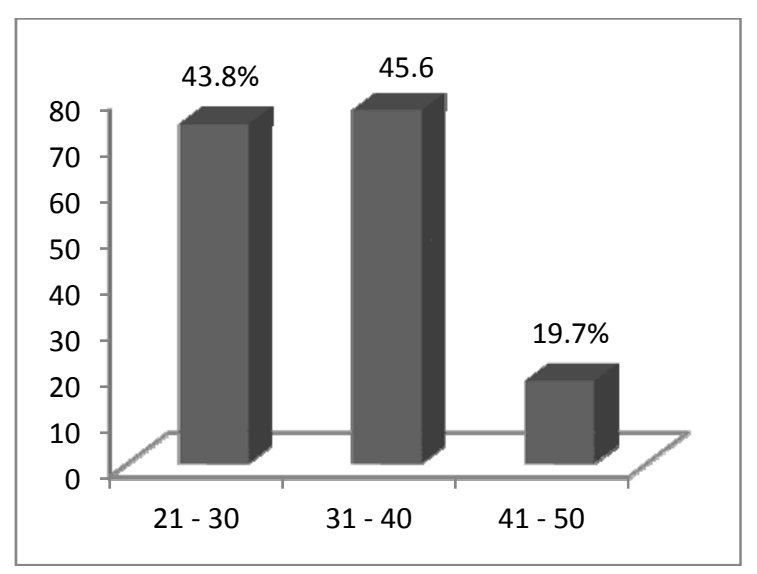

Figure 1. Age Range of Respondents

The analyses of the eight statements for course value (Figure 2) resulted in a mean score of 4.36 , whilst for student engagement and with the same number of statements, (Figure 3), the mean score was 4.48 .

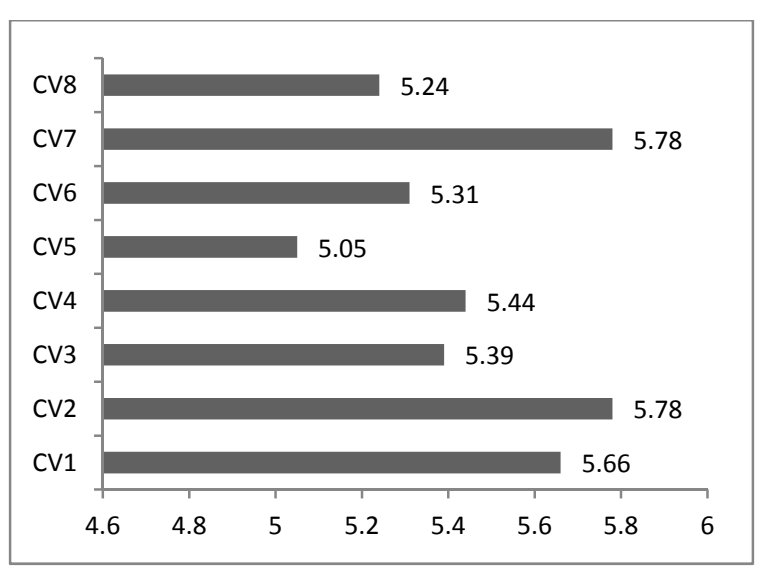

Figure 2. Analysis of the Course Value

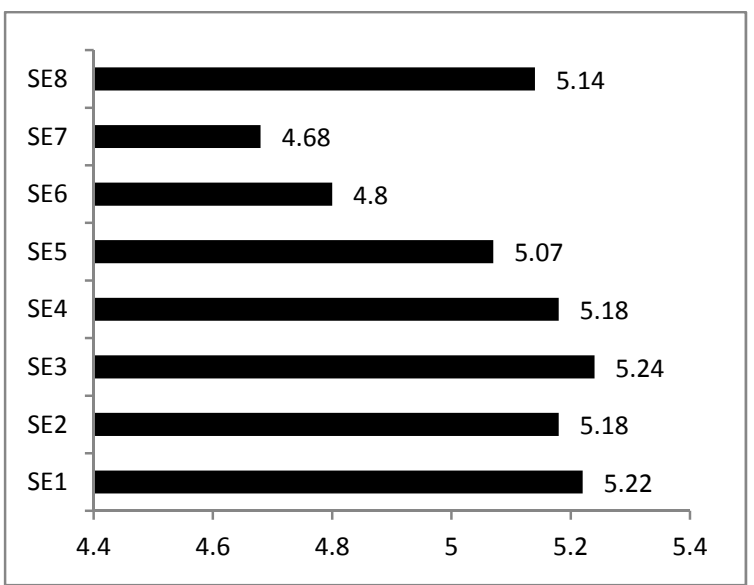

Figure 3. Analysis of the Student Engagement

The discussion on the findings will be elucidated in the following section.

\section{Discussion}

The findings showed that the most number of students fall within the age range of 31-40 years. At this age, most adult students are established in their career, that is, they have a permanent job and the next step would be for better career prospects in preparation for retirement at 58 years - the maximum retirement age for civil servants. Also, the findings generated mean scores for student engagement and course value of 4.36 and 4.48 respectively. These scores fall between the scales of 4 (Neutral) to 5 (Agree). In fact, the mean for student engagement is at the lower end of four compared to course value which is closer to five. Clearly both scores are not significant or convincing particularly for engagement. Since course value measures how valuable a student feels a given course is, and whether the course stimulated the student's interest 
in the subject matter for real-world application [10] [17], a higher score would positively correlate with engagement. From responses or complaints received through InED's electronic forum, students have consistently indicated that concentrating on their studies is difficult. Correlating this to the findings, there is sufficient evidence that ICT-based education would require that creativity on the instructors' parts.

\section{Conclusion}

To conclude, it is recommended that instructors should try to stimulate learning by including realworld projects which can assist the adult students in identifying learning goals which, in turn could generate increased motivation and learning. This should be an easy task as most of the students are working and undertaking their studies part-time. By using their workplaces as examples, the outcome would be a win-win situation for both the students and instructors.

\section{Acknowledgements}

We would like to thank the Research Management Institute, Universiti Teknologi MARA for funding our project through the Excellence Fund scheme.

\section{References}

[1] Beins, B.C. Research Methods: A Tool for Life. Boston, MA: Pearson, 2004.

[2] Biggs, J.B. and Tang, C. Teaching for quality learning at university. Maidenhead, Open University Press/McGraw-Hill Education. 2007.

[3] Bourdieu, P. The forms of capital, In Halsey, A. et al. (eds) Education Culture Economy Society. Oxford University Press, Oxford, 1997.

[4] Corno, L. and Mandinach, E.B. The role of cognitive engagement in classroom learning and motivation. Educational Psychologist, 18(2), pp. 88108, 1983.

[5] Dahan, H. M. and Baba, J. "A qualitative approach to adult learners' understanding of a supportive learning environment: A case study", Malaysian Journal of University Education, UPENA-UiTM, Malaysia, June 2005, pp.33-46.

[6] DeRouin, R.E., Fritzsche, B.A. and Salas, E. Elearning in Organizations. Journal of Management, 13(6), pp. 920-940, December 2005.

[7] Duffy, T.M. and Kirkley, J.R. (eds). Learnercentered theory and practice in distance education:
Cases from higher education. Mahwah, NJ, Lawrence Erlbaum Associates, 2004.

[8] Fallows, S. and Bhanot, R. (eds). Quality issues in ICT-based higher education. Birmingham, UK, Routledge, 2005.

[9] Heiman, G.W. Understanding Research Methods and Statistics: An Integrated Introduction for Psychology. $2^{\text {nd }}$ edition. : Houghton Mifflin, Boston, MA., 2001.

[10] Jurow, A.S. Shifting engagements in configured worlds: Middle school mathematics students' participation in an architectural design project. The Journal of the Learning Sciences, 14(1), pp. 35-67, 2005.

[11] Morgan-Klein, B. and Osborne, M. The concepts and practices of lifelong learning. Madison Ave., NY, Routledge, 2007.

[12] Nachmias, C-F. and Nachmias, D. Research Methods in the social sciences, $5^{\text {th }}$ ed, London, England, Arnold, 1996.

[13] Neuman, W.L. Social research methods: qualitative and quantitative approaches, $5^{\text {th }}$ ed, Boston, MA, Pearson, 2003.

[14] Organization for Economic Co-operation and Development (OECD). Beyond rhetoric: Adult learning policies and practices, Paris: OECD, 2003.

[15] Pagano, R.R. Understanding Statistics in the behavioral sciences, $8^{\text {th }}$ ed, Belmont, CA, Thomson, 2007.

[16] Poon, W.C.; Low, K.L-T. and Yong, D.G-F. A Study of Web-based Learning Environment in Malaysia. The International Journal of Educational Management, 18(6), pp. 374-385, 2004.

[17] Richardson, J.C. and Newby, T. The role of students' cognitive engagement in online learning. The American Journal of Distance Education, 20(1), 23-37, 2006.

[18] Selwyn, N., Gorard, S. and Furlong, J. Adult learning in the digital age, New York, NY, Routledge, 2005.

[19] Stangor, C. Research Methods for the Behavioral Sciences. $2^{\text {nd }}$ Edition. New York. Houghton Mifflin, 2007.

[20] Tham, C.M. and Werner, J.M. Designing and evaluating e-learning in higher education: A review 
International Journal of Digital Society (IJDS), Volume 2, Issue 1, March 2011

and recommendations, Journal of Leadership and Organizational Studies, 11(2), pp. 15-25, 2005.

[21] Volery, T. and Lord, D. Critical Success Factors in Online Education. The International Journal of Educational Management. 14(5), pp. 216-223, 2000.

[22] Warburton, K. Deep Learning and Education for Sustainability. International Journal of Sustainability in Higher Education, 4(1), 44-56, 2003. 